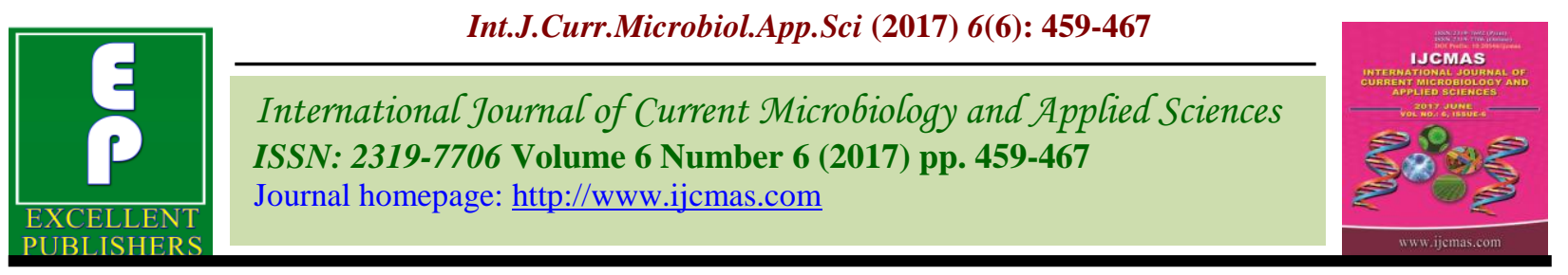

Original Research Article

https://doi.org/10.20546/ijcmas.2017.606.053

\title{
A Comparison between Tilapia zilli (Gervais, 1748) (Preciformes: Cichlidae) and Common Carp Cyprinus carpio (Linnaeus, 1758) (Cypriniformes: Cyprinidae) by Staining Bone Technique
}

\author{
Mohammed I. Ghazwan Al-Janabi* \\ Iraq Natural History Research Center and Museum / University of Baghdad, Iraq \\ *Corresponding author
}

\begin{tabular}{|c|c|}
\hline & A B S T R A C T \\
\hline $\begin{array}{l}\text { Ke y w o r d s } \\
\text { Staining, } \\
\text { Common carp, } \\
\text { Tilapia zilli, } \\
\text { Muscular tissue, } \\
\text { Skeleton. }\end{array}$ & \multirow{3}{*}{$\begin{array}{l}\text { Sixteen species of fish belong to nine families have been stained. This } \\
\text { study focused, in particular, on two species which are Cyprinus carpio and } \\
\text { Tilapia zilli due to their existence in the Iraqi internal waters. Alcian blue } \\
\text { and Alizarin red have been used in staining the samples of study. This } \\
\text { study was prepared to describe the differences between Cyprinus carpio } \\
\text { and Tilapa zilli families. Some of the anatomic features have been appeared } \\
\text { by which the diversity and the difference can be studied in the muscular } \\
\text { tissue and the skeleton for both species and some other species of the study. } \\
\text { The objective of this study is the possibility of classification and diagnosis } \\
\text { these two species by staining the bones and tissues. }\end{array}$} \\
\hline Article Info & \\
\hline $\begin{array}{l}\text { Accepted: } \\
\text { 05 May } 2017 \\
\text { Available Online: } \\
\text { 10 June } 2017\end{array}$ & \\
\hline
\end{tabular}

\section{Introduction}

The method of staining bones is considered as one of the adopted means in studying the tissues and bones as well as the organs by which a comparison between fish species can be made as of Potthoff (Potthoff, 1984). The main objective of this study is to identify the tissue and skeleton differences between some species of fish which can enhance the taxonomic studies other than the taxonomic differences between the traditional and known kinds. The whole fish can be successfully stained or some parts of fish body such as bone and tissue by two clear colors as noted (Potthoff et al., 1977). In fish, the diagnosis after staining depends on the spine shape, fin rays branches in addition to the teeth, pharyngeal teeth, gill lamellae, branched and non- branched anal fin, completed bone fins and fatty fins have no bones as it has been referred to (Coad, 2015). The distribution and diversity of bones shape give an important role to the emergence and development of fish species in addition to the different relations between these species as it illustrated (Doadrio, 1990). Information on these relations, emergence and development are available in different species of fish depending on the diversity and distribution of bones in the fish skeleton (Keivany et al., 1998; 2004; 2006; 2014a). The difference in distributing the internal muscles between the bones and connected with the joint tissues 
illustrates the movement pattern of the different species of fish. The fish swimming method varies depending on the body shape especially the internal muscles between the bones (Wenjie et al., 2015). Some studies for staining internal tissues of fish, especially the bones and connective tissues, illustrated the species of muscle tissues connected with the bones by connective tissue as it has referred to (Gemballa et al., 2003) and confirmed (Danos et al., 2012).

The technique of staining bones and connective tissue of cartilage and nerves can be used to study the cartilage and bones in different stages of development in most of vertebrates. This technique firstly was applied on the Bats and Rodents (Natalia et al., 2009).

\section{Materials and Methods}

The procedures followed in preparing the fish samples and staining them as in the methods and (Taylor et al., 1985) will be as follows:

The materials which have been used in preparing the staining are:

\section{1- Formalin $10 \%$}

2- Ethanol alcohol $(30 \%, 70 \%, 95 \%)$

3- Hydrogen peroxide $15 \%+., 1$ Potassium hydroxide $85 \%$

4- Acetic acid 30\% + Ethanol 70\% + Alcian blue

5- Borax 30\%

6- Borax 30\% + Trypsin enzyme

7Potassium hydroxide $40 \%$ + Glycerin $60 \%$

8- Potassium hydroxide $40 \%$ + Glycerin $60 \%$

\section{Method of work}

The fish are saved in formalin solution with a concentration of $10 \%$ for five days, then the samples are washed with running water and saved for two days in pure water to remove the formalin traces, hence they are washed again and kept in ethanol alcohol in concentration $30 \%$ for 2-3 days depending on the fish size. If the fish length is more than 15 $\mathrm{cm}$, they will be saved for two days, after that they are saved in ethanol alcohol in the concentration of $70 \%$ for two more days depending on the samples size.

The innards of fish were removed.

The fish samples are saved in Ethanol alcohol in concentration $95 \%$ for two more days for fish with the length over than $15 \mathrm{~cm}$ for one week.

The samples are kept in solution contains (Acetic acid 30\% + Ethanol alcohol 70\% + some Grams of Alcian blue) where the solution color is changed to be very dark blue, if the length of the sample is less than $8 \mathrm{~cm}$, they will be kept for one day, but if the length is $8-10 \mathrm{~cm}$,they will be kept for one day and half.

The samples are kept in the saturation Borax solution for one day if their size more than 10 $\mathrm{cm}$ and the solution should be changed when it gets blue color.

The samples are kept in a solution contains (Hydrogen peroxide $15 \%+$ Potassium hydroxide $85 \%$ ) for only one hour to complete the bleaching process.

The samples are returned to the saturation Borax solution of which Trypsin enzyme is added and change the solution when the color is being blue. It is better to change the solution each 7 days until the ratio of clear will be more than $60 \%$ where the spine can be seen with blue color, bearing in mind that this samples can be kept in the day time to accelerate the staining process.

The samples are kept in solution contains of (Potassium hydroxide 1\%), then Alizarin red 
is added to it until the solution color is being very dark pink. The samples are saved from one to three days, no more until the bones seem with pink color.

The samples are returned again to the saturation Borax solution and Trypsin as in the step 7 and kept in it for additional one week.

The samples are kept in solution contains (Potassium hydroxide 70\% + Glycerin 3\%)for 2-7 days then in another solution (Potassium hydroxide $40 \%$ + Glycerin $60 \%$ ) for 2-7 days. The period depends on the fish size and length.

\section{Results and Discussion}

The samples of Cyprinidae include Cyprinus carpio in figures 1 and 2, Gara rufa in figure 3, Puntius tetrazona in figure 4 and Balantiocheilos melanopterus in figure 5.

While the Cichlidae includes the samples from the Tilapia zilli as in the figure 6 and Platax scalaris as in figure 7.

The Poecilia latipinna was the sample of Poecilidae as in figure 8.

From the Characidae, two samples which are Gymnocorymbus ternetz (Figure 9), Hyphessobrycon eques (Figure 10) and Loricariidae, the sample Hypostomus plecostomus (Figure 11). While the Hemibagrus planiceps in figure 12 is the sample of Bagridae.

There are two kinds of Anabantidae, the Trichopodus trichopterus (Figure 13) and Colisa lalia (Figure 14), while Scatophagus argus is the sample of Scatophagidae (Figure 15). Toxotes jaculatrix was the sample of Toxotide family in figure 16, while Rhinogobiops nicholsii is the sample of
Gobiidae family (Figure 17). The description of two species Cyprinus carpio and Tilapia zilli was in the figures 1,2 and 6 due to their abundance in the Iraqi internal waters. It has been noticed a difference in distributing bones in the spine in addition to the difference in distributing the bones' rays especially in the dorsal and anal fins. Also, the shape of skull between these two species is different. In general, this anatomy distinguishes between these families, it has been noticed that the distribution of rays in the dorsal and anal fins of the Cichlidae have more branches and distribution than the Cyprinidae which the majority of its members are characterized with short dorsal and anal fins except for some of the species such as carp, carassius and koi which are characterized with long dorsal fins and short anal fins as in the rest of the Cyprinidae in figures 3,4 and 5, on the contrary of the Cichlidae of which bone rays in the dorsal and anal are characterized to be strong as in the figures 6 and 7 and mentioned in (Paula et al., 2002).

The spine begins to be curved at the end of the tail towards the body cavity. It is noticed that the number of vertebras extending from the end of the tail to the area of curvature in the spine towards the back are $13-14$ in Cichlidae in terms of species, but they are 2325 in the Cyprinidae. There is no curvature in the spine in some species of Gobiidae (Figure 17), Loricariidae (Figure 11) in addition to Bagridae in figure 12 as it has been referred to (Elizabeth et al., 1998).

For Cyprinus carpio, there are eight pairs of muscles associated with the pharynx responsible on raising the fifth gill arch and the function of these muscles is to facilitate the process of chewing and move the pharyngeal teeth by crushing and grinding of food during closing the mouth in addition to expanding the area of pharynx to facilitate the swallowing which is different from Tilapia 
zilli as the teeth are in the front of the head (Joseph et al., 1971). The carp body is characterized with a length of four times than its height, the Carp fish that have been grown are larger than Carp in nature and they are being larger in size with better food sources and good breeding water (Wilt et al., 2008;
Füllner et al., 2011). Fish are generally subject to external factors and conditions that vary according to the age of the fish, causing deformities in many of the body parts, especially the areas of the head and the spine, in addition to the dorsal and anal fins.

Fig.1 Cyprinus carpio

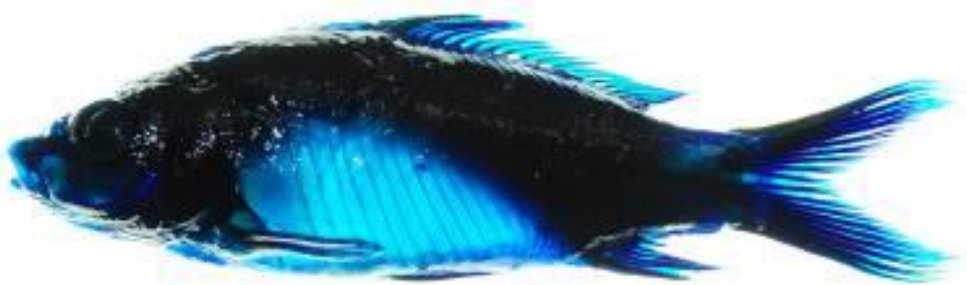

Fig.2 Cyprinus carpio

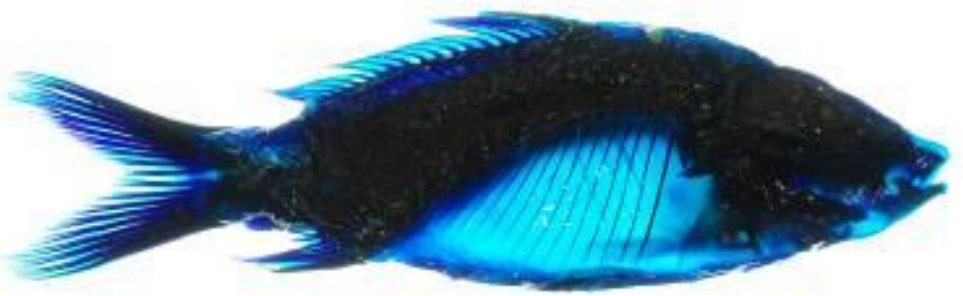

Fig.4 Puntius tetrazona

Fig.3 Gara rufa
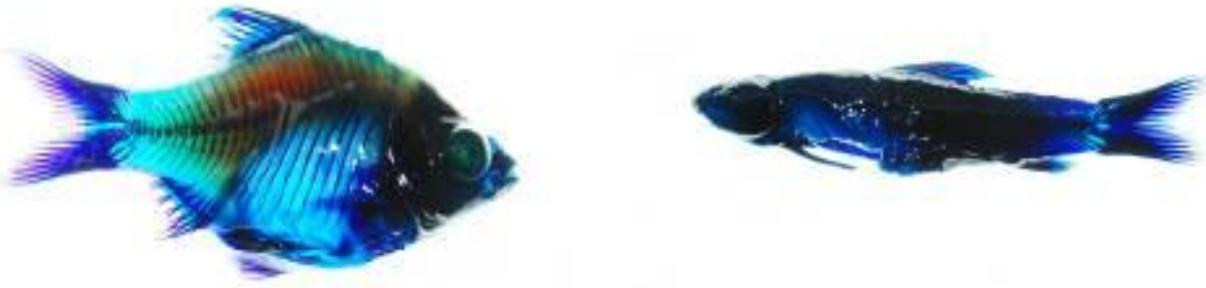

Fig.5 Balantiocheilos melanopterus 
Fig.7 Platax scalaris

Fig.6 Tilapia zilli
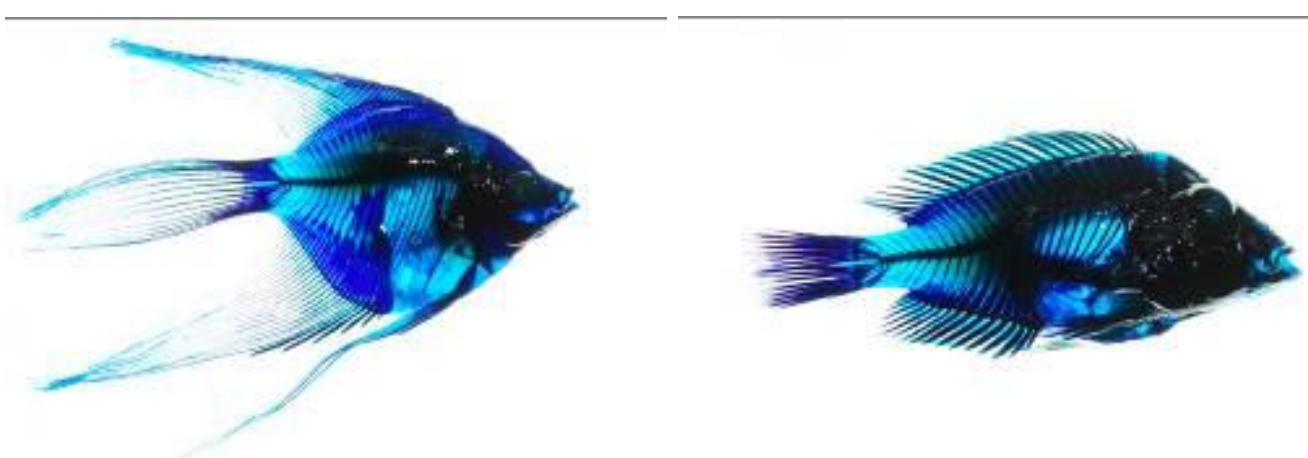

Fig.8 Poecilia latipinna

Fig.10 Hyphessobrycon eques

Fig.9 Gymnocorymbus ternetz

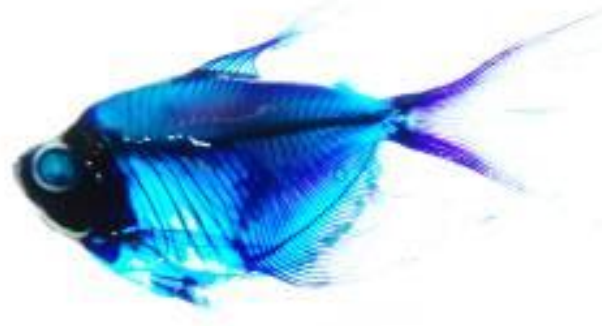

Fig.11 Hypostomus plecostomus

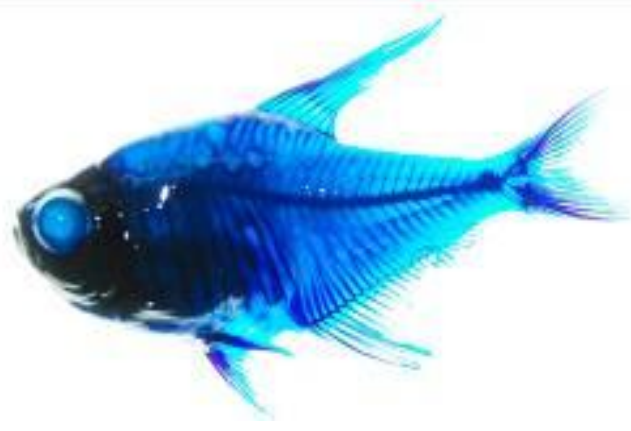

Fig.12 Hemibagrus planiceps
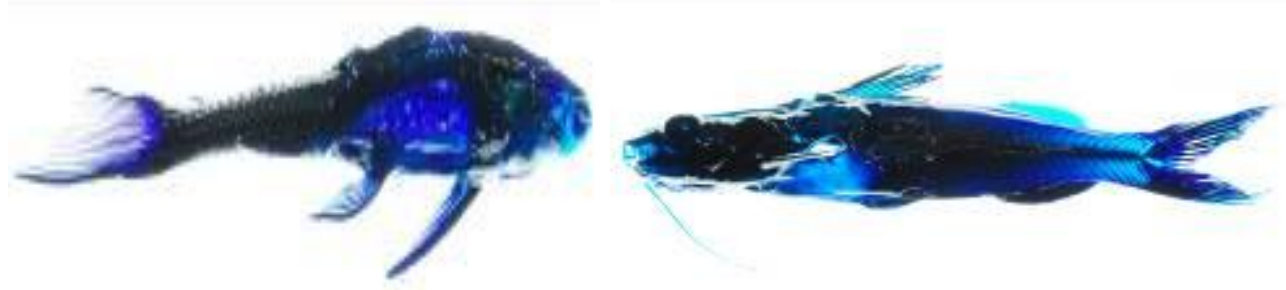


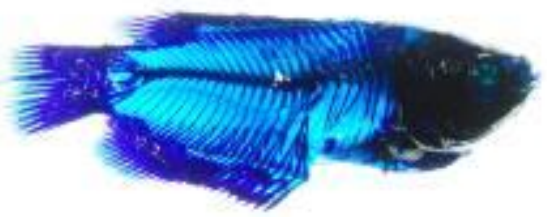

Fig.15 Scatophargus argus

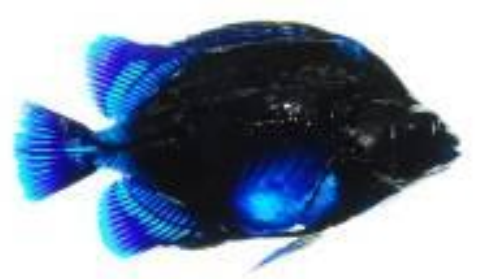

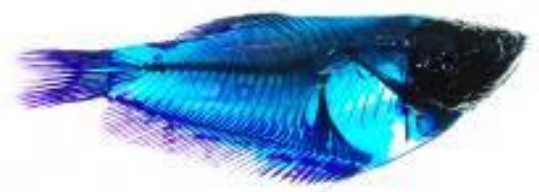

Fig.16 Toxotes Jaculatrix

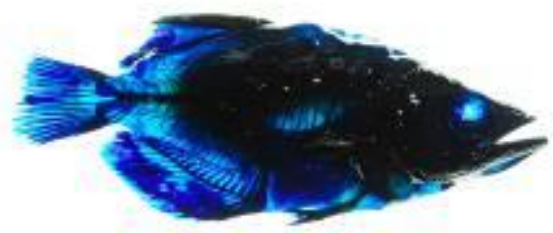

Fig.17 Rhinogobiops nicholsii

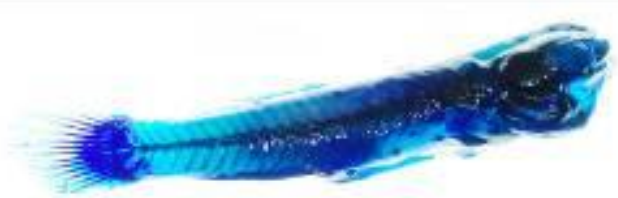

Fig.18 the pelvic fin modified in Gourami fish

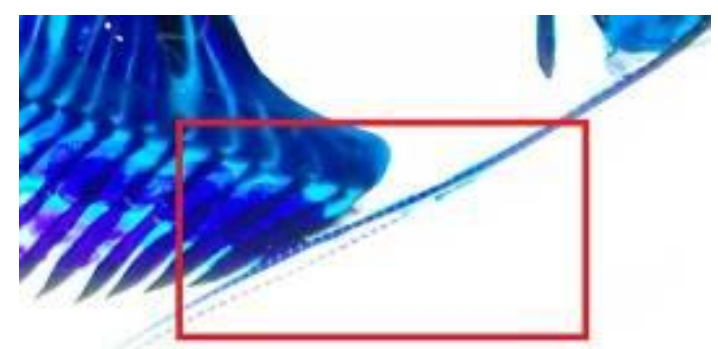

Fig.19 Distribution the bones and cartilage in the Tilapia zilli

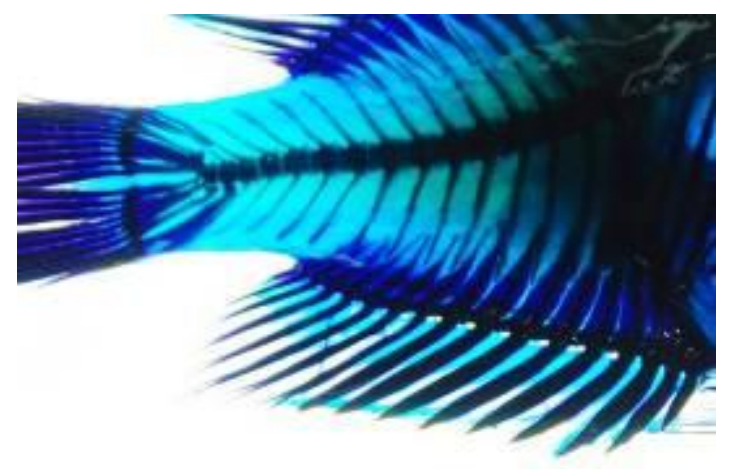


These deformities may vary from one kind to another or even in the same kind between different kinds of fish, causing many errors in the diagnosis and classification of kinds as it has been referred to (Eissa et al., 2009). Muscle tissues vary in the fish depending on type and methods of swimming by the species, as it is noted that the fine muscle tissues between the plates of muscle around the spine axis are different between the species and may disappear in other species. It may be consonant by evolution of these species in previous years and it is absent in some species that differ in swimming methods and swimming site in the water. Carp fish take advantage from the entire water column up and down in addition to being a fish that are good swimmers, searcher and disinterest at the bottom in a contrast to the behavior of Tilapia zilli in swimming and staying in a certain area of water depth. It is also known that Tilapia is found in shallow areas more than deep water opposite carp that does not make this point important in their behavior while swimming and feeding. In general, the fish in this study differed by their tissue bones between the muscular tissue at the end, as in Cyprinidae, carp one of it, these bones were single-sided, non-branched, and frontal bones were with single branched ends. In some species, double-branched end differed according to the species and environmental factors affecting fish in the initial stages of their life that give a nonsymmetry form and distribution of the tissue as in (Li Ling et al., 2013; Chen, 1987; Ke Zhong-He et al., 2008).

The Gourami in figures 13 and 14 do not have real pelvic fins, but rather modified to long thin string fins, that control the movement of fish as in real fins when enlarged, we find that it looks like a group of small bones as in the phalanges arranged in a linear shape which gives the long string shape and in fact a pelvic fin modified as shown (24) (Figure 18). The
Cyprinus carpio and Tilapia zilli differ from local fish in terms of bone distribution and skull shape with Iraqi species. However, it is known that the common carp fish belong to the family of the Cyprinidae, which is the same Iraqi family of Cyprinidae, but the carp belongs to Cyprinus While most Iraqi carp species belong to Barbus, from here, there were clear tissue muscle and bone differences beside the bone distribution and shape (Doadrio, 1990). As for the different Tilapia species, the researchers agree that they follow the new wholly ossified fish and it is clear from the consistency of bone distribution in addition to bone strength and its appearance during staining, unlike the normal carp fish in addition to the difference in tissue and cartilage composition in Tilapia fish from carp fish as shown in figure 19, the color of cartilage is staining gradually in a contrast to common carp fish, as cartilage is more common and thin bones are present during the muscle tissue of the body cavity especially at the front of the body. These results are consistent with what is shown (Loretz et al., 2012).

It should be noted that the differences happened in bone shape between the different species or even between one species individuals are exposed different pollutants in their different environments that affect the distinguish between healthy bones and deformed bones due to the pressure of various pollutants on fish in the early stages of life, especially mineral contaminants. Such as lead, mercury and carbon contaminants represented by hydrocarbons, as well as some pesticides that negatively affect the life of fish as it has been indicated (Snježana et al., 2015; Al-Harbi, 2001).

\section{References}

Al-Harbi, A.H. 2001. Skeletal Deformities in Cultured Common Carp Cyprinus 
carpio L., Asian Fisheries Sci., 14: 247254.

Chen Xin-Yu. 1987. Studies on the skeleton of leuciscine fishes of china, with particular reference to its significance in taxonomy, Institute of Zoology, Academia Sinica, Beijing, Acta Zootaxonomica Sinica.

Coad, B. 2015. Fresh water fishes of Iran. Www.briancoad.com. Retrieved 9/3/2015.

Danos, N. and Ward, A.B. 2012. The homology and origins of intermuscular bones in fishes: phylogenetic or biomechanical determinants? Biol. J. Linn. Soc., 106: 607-622.

Dingerkus, G., Uhler, L.D. 1977. Enzyme clearing of Alcian Blue stained whole small vertebrate's dor demonstration of cartilage. Stain Technol., 52(4): 229232.

Doadrio, I. 1990. Phylogenetic relationships and classification of western palaearctic species of the genus Barbus (Osteichthyes, Cyprinidae). Aquatic Living Res., 3(4): 265-282.

Doadrio, I. 1990. Phylogenetic relationships and classification of western palaearctic species of the genus Barbus (Osteichthyes, Cyprinidae). Aquatic Living Res., 3(4): 265-282.

Eissa, A.E., M. Moustafaa, I.N. El-Husseinyb, S. Saeidc, O. Salehd, T. Borhan. 2009. dentification of some skeletal deformities in freshwater teleosts raised in Egyptian aquaculture. Volume 77, Issue 3, Pages 419-425.

Elizabeth, L., Brainerd and Sheila, N., Patek. 1998. Vertebral Column Morphology, C-Start Curvature, and the Evolution of Mechanical Defenses in Tetraodontiform Fishes. American Society of Ichthyologists and Herpetologists (ASIH), Vol. 1998, No. 4 (Dec. 30, 1998), pp. 971-984.
Froese, R. and Pauly, D. (Eds.). 2007. FishBase [online] version (01/2007). Available from: www.fishbase.org \{Accessed April 2007\}.

Füllner, G., Pfeifer, M., Langner, N. 2011. "Karpfenteichwirtschaft" (PDF). Sächsische Landesanstalt für Landwirtschaft.

Gemballa, S. and Britz, R. 1998. Homology of intermuscular bones in acanthomorph fishes. Am. Mus. Novitat., 3241: 1-25.

Gemballa, S., Ebmeyer, L., Hagen, K., Hannich, T., Hoja, K., Rolf, M., Treiber, K., Vogel, F. and Weitbrecht, G. 2003. Evolutionary transformations of myoseptal tendons in gnathostomes. Proc. R. Soc. B Biol. Sci., 270: 12291235.

Joseph, T., Eastman. 1971. The pharyngeal bone musculature of th carp, Cyprinus carpio Journal of Morphology. Volume 134, Issue 2.June 1971.Pages 131-140.

Ke Zhong-He, Zhang Wei, Jiang Yan, Bao Bao-Long. 2008. Developmental Morphology of the Intermuscular Bone in Hypophthalmichthys molitrix. Chinese J. Zool.

Keivany, Y. 2014a. Comparative osteology of the suspensorial and opercular series in representatives of the eurypterygian fishes. Iranian J. Ichthyol., 1(2): 73-90.

Keivany, Y. and Nelson, J.S. 1998. Comparative osteology of the Greek ninespine stickleback, Pungitius hellenicus (Teleostei, Gasterosteidae). $J$. Ichthyol., 38(6): 430-440.

Keivany, Y. and Nelson, J.S. 2004. Phylogenetic relationships of sticklebacks (Gasterosteidae), with emphasis on ninespine sticklebacks (Pungitius spp.). Behaviour, 141(11/12): 1485-1497.

Keivany, Y. and Nelson, J.S. 2006. Interrelationships of Gasterosteiformes (Actinopterygii, Percomorpha). $J$. Ichthyol., 46(suppl. 1): S84-S96. 
Li Ling, Zhong ZeZhou, Zeng Ming, Liu ShaoJun, Zhou Yi, Xiao Jun, Wang Jun and Liu Yun. 2013. Comparative analysis of intermuscular bones in fish of different ploidies. Key Laboratory of Protein Chemistry and Developmental Biology of Ministry of Education of China, College of Life Sciences, Hunan Normal University, Changsha 410081, China. Vol.56 No.4: 341-350.

Loretz, C.A., Pollina, C., Herberger, A.L., Hyodo, S., Takei, Y. 2012. Skeletal tissues in Mozambique tilapia (Oreochromis mossambicus) express the extracellular calcium-sensing receptor. Comp. Biochem. Physiol. A Mol. Integr. Physiol., 163(3-4): 311-8. doi: 10.1016/j.cbpa.2012.07.015. Epub 2012 Aug 3.

Natalia Cortés-Delgado, Jairo Pérez-Torres and Julio Mario Hoyos. 2009. Staining Procedure of Cartilage and Skeleton in Adult Bats and Rodents. Int. J. Morphol., 27(4): 1163-1167.

Paula, M., Mabee, Patricia, L., Crotwell, Nathan, C., Bird, Ann, C., Burke. 2002. Evolution of median fin modules in the axial skeleton of fishes. J. Experimental Zool., Volume 294, Issue 215, Pages 77-90.

Potthoff, T. 1984. Clearing and staining techniques. In: Ontogeny and
Systematics of Fishes (based on an international symposium dedicated to the memory of Elbert Halvor Ahlstrom). H.G. Moser, W.J. Richards, D.M. Cohen, M.P. Fahay, A.W. Kendall, Jr., and S.L. Richardson, eds. Lawrence, KS, Special Publication 1, American Society of Ichthyologists and Herpetologists, Allen Press, pg. 35-37.

Snježana Kužir, Luka Maleničić, Damir Stanin, Tajana Trbojević Vukičević, Ivan Alić and Emil Gjurčević. 2015. Description of head deformities in cultured common carp (Cyprinus carpio Linnaeus, 1758). Veterinarski Arhiv, 85(4): 437-449, 2015.

Taylor, W.R., van Dyke, G.C. 1985. Revised procedures for staining and clearing small fishes and other vertebrates for bone and cartilage study. Cybium, 9: $107-119$.

Wenjie Yao, Yaoping, Xiaoling Gong, Jiaming W. and Baolong Bao. 2015. Different ossification patterns of intermuscular bones in fish with different swimming modes. Published by the Company of Biologists Ltd, Biol. Open, 4: 1727-1732 doi:10.1242/bio.012856.

Wilt, R.S.de., Emmerik, W.A.M. 2008. "Kennisdocument Karper Sportvisserij Nederland"

\section{How to cite this article:}

Mohammed I. Ghazwan Al-janabi. 2017. A comparison between Tilapia zilli (Gervais, 1748) (Preciformes: Cichlidae) and common carp Cyprinus carpio (Linnaeus, 1758) (Cypriniformes: Cyprinidae) by Staining Bone Technique. Int.J.Curr.Microbiol.App.Sci. 6(6): 459-467. doi: https://doi.org/10.20546/ijcmas.2017.606.053 